\title{
INTERVIEW
}

\section{TEKNOLOGI, TEKNIK, TEKNE, TING, T ...}

\author{
En duelog mellem Inger Sjørslev og Lars Botin
}

\section{MY MADSEN OG PERLE MØHL}

Vi har indstævnet to forskere, som begge har arbejdet med, forsket i og skrevet om teknologi, men fra to forskellige videnstraditioner og på to forskellige forskningsinstitutioner. Vi forestiller os, at de kan have kontrasterende indgange til og opfattelser af, hvordan man arbejder med og definerer teknologi. Vi kalder derfor diskussionen en ,duelog“ [og deltagerne for „diskotanter", men det er en anden sag], ud fra en idé om, at det kan blive til en meget ophedet diskussion, hvor der skal afstikkes og forsvares territorier med kårde eller pistol. Vi stiller os gerne til rådighed som adjudanter, der kan ildne yderligere til kamp. Men ...

Vi aftaler at mødes i toppen af Maersk Tårnet, hvor der kommer cappuccino ud af en iPad - det er, synes vi, en passende hi-tech-kontekst for duelogen, og så er der god udsigt. Men Danmark bliver lukket ned, og vi må tage duelogen over nettet. Vi afprøver nogle af de mange mødeplatforme, som vi har vænnet os til at bruge, men det trækker tænder ud - snart kan den ene ikke logge på, snart virker den andens mikrofon ikke. Der går et par dage med forsøg, og endelig lykkes det, dog med nogle mindre kommunikationsglitches. De er dog af teknologisk og ikke af personlig eller fagtraditionsmæssig karakter.

Perle: Nu optager jeg altså ... [der grines]. Vi skulle jo have optaget alt det inden, så vi havde en slags coronaforord [der grines]. Inger: Hvorfor er My der ikke? Perle: Ja, vi skal vi have My med. Lars: Jo, jeg har My. Perle: Har du det?! Lars: Jep! Inger: Jeg har ikke. Lars: Jo, jeg har My i mine ... ører ... My: OK ... Kan I andre høre mig nu også? Perle: Jaaah. Gjorde du noget? My: Ncee ... Inger: Nå. Hvad skal vi snakke om? Lars: Tiden går. My: Jeg føler, at vi burde snakke om, hvordan vi kunne lave et forskningsprojekt om alt det, vi lige har oplevet. Perle: Ja, der bliver allerede lavet en masse nu om telekommunikation og hjemmearbejde. My: Tydeligvis ikke nok! 


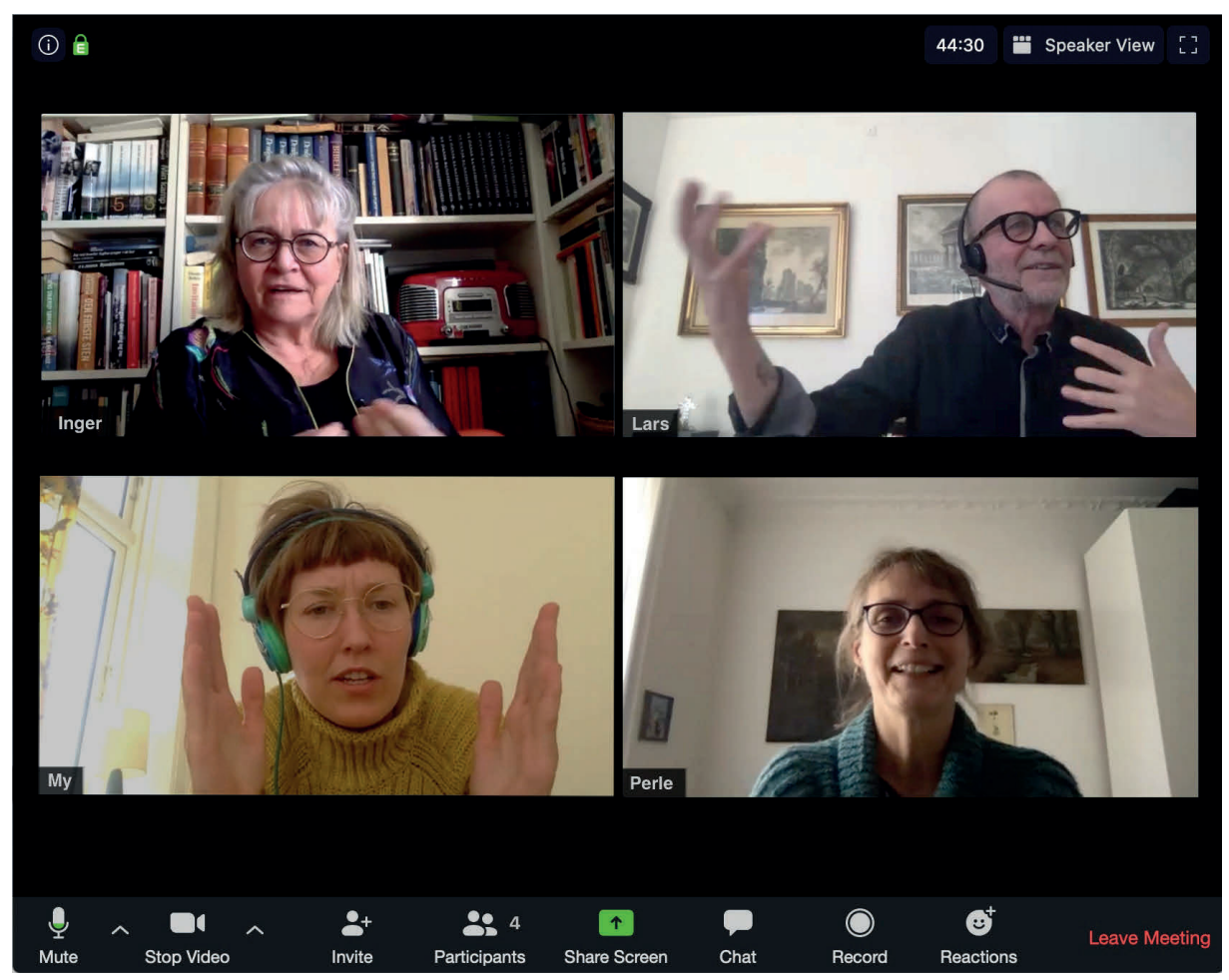

Perle: I er så blevet indkaldt som ,, diskotanter “ til denne ,, duelog “. Men I kender ikke hinanden, vel?

Inger: Nej.

Lars: Nej.

Inger: Hej Lars!

Lars: Hej Inger!

Perle: Inger er antropolog og har arbejdet med ting og genstande hele sit liv, tror jeg, som antropolog og museumsinspektør. Og med kropslige teknologier: candomblé og bescettelse i Brasilien. Og faktisk også med ,, diffusion “, med hvordan tingene har bevaget sig fra Afrika til Brasilien og så tilbage igen.

Inger: Det kan man godt sige.

Perle: Og Lars er kunsthistoriker og har også arbejdet med ting og med spørgsmålet om, hvad ting og genstande er. Med sundhedsteknologier og design og medier og med at definere teknoantropologi. Og med postfcenomenologi. Og så 
havde vi de her punkter på dagsordenen: at I kort introducerer jer selv, jeres fag, tradition, og hvilket møde I har haft med teknologi i jeres forskning, sådan ganske kort. [Perle forklarer, at det gerne må tage form af en pingpong, en ,,duelog "].

Inger: Det er jo spændende, hvordan det bliver til en „duelog“ - når I nu har opfundet det begreb, så må vi hellere gøre det sådan. OK, så begynder jeg med det første spørgsmål: hvor jeg kommer fra. Det er meget tydeligt og klart - det vil I opdage, når jeg snakker videre - at min forståelse og brug af begrebet teknologi helt klart er udsprunget af den antropologiske fagtradition. Men jeg havde lyst til i denne anledning, når I nu spurgte mig, at fortælle jer, at jeg begyndte min studiekarriere i psykologien. Og faktisk på en eller anden måde har hele mit faglige liv været præget, inspireret måske, af det, jeg lærte i psykologien med dens teknologiske indgang til den eksperimentelle psykologi. Altså kognitionsog perceptionsfænomener. Og psykologien har en meget mere individualistisk tilgang til tingene end antropologien og etnografien, og det var derfor, jeg forlod den. Jeg ville ud i noget mere kulturelt, samfundsorienteret og kollektivt og sådan noget. Men jeg har haft megen glæde af det grundlag, jeg fik i psykologien, med dens meget mere - og det kalder jeg så i dagens anledning - teknologiske, altså eksperimentelle tilgang. Vi lavede laboratorieforsøg og sådan noget ... Kan I høre mig? [De andre svarer bekræftende]. Jeg vil ikke gøre så meget ud af det, for vi skal jo også videre, men i psykologien laver man laboratorieforsøg om kognition, sanseapparatet, perception og sådan noget, og den der indsigt $i$, at en fysisk stimulus ikke er det samme som det, sanseapparatet opfatter, det ved vi måske alle sammen, men det har været en god baggrund for mig til alt, hvad jeg senere har lavet. Men jeg kommer udpræget fra den antropologiske fagtradition. Der har jeg været $\mathrm{i}$ årevis, ikke. Og det har bestemt stort set alt, hvad jeg har beskæftiget mig med. Så vil jeg lige tilføje hurtigt, at ... [kort afbrydelse, problemer med mikrofon] ... Så har jeg været i en slags mesterlære i museumsverdenen, og det har også præget mig. Med museumsverdenens orientering mod materiel kultur, kunst og æstetik og etnografiske genstande. Det er der også en eller anden form for teknologi i, som jeg nok vil komme tilbage til.

My: Så lad os gå over til dig, Lars.

Lars: Jamen, Perle var inde på det. Jeg kommer fra kunsthistorie, men før det har jeg faktisk en klassisk sproglig studentereksamen, som har været ret bestemmende for min tilgang i det at få afdækket, hvad begreberne indebærer, hvad deres oprindelige betydning var. Og så peger det måske allerede for nogle af jer tilbage til en filosofisk tradition med afsæt i hermeneutikken. Det, jeg peger på, er primært Gadamar og i den grad Heidegger. Jeg kan ikke fraskrive mig det, at jeg i sidste ende nok er ærkeheideggerianer og nok også i min teknologiforståelse - ikke 
blot heideggerianer, men det ligger ligesom latent, også i min fænomenologiske tilgang. Så det med at afsøge begrebernes grundbetydning i forskellige sproglige, lingvistiske kontekster har altid ligget mig meget på sinde, og faktisk så mener jeg - og det har jeg gjort en del ud af de senere år - at Heidegger grundlæggende er blevet misforstået på grund af fejlagtige oversættelser til engelsk af nogle af hans kernebegreber. Det kan jeg måske også vende tilbage til, fordi det er noget, jeg arbejder ret intenst med. Så der er en eller anden navlestrengsforbindelse til en tysk filologi og en tysk fænomenologisk udlægning af tingene. Jeg har det lidt ondt med teknologibegrebet. Men det vil jeg vende tilbage til, nu I spørger, hvad teknologi er, i et senere spørgsmål. Andre erfaringer, jeg har gjort mig undervejs, som har været bestemmende for min tilgang til teknologi og min forståelse af teknologi, er, at jeg levede i prekariat, som det hedder i dag, tilbage i 1980'erne, det vil sige, jeg ernærede mig som portørafløser på diverse hospitaler, som chauffør på frysebiler i Rom og som gulvafsliber. Og det betyder i og for sig, at den der forståelse af, hvad teknologien er, og hvad den betyder i relation til de rum, hvor den vikler sig ud i min direkte anvendelse - deraf min forståelse af hospitalet - faktisk er ret bestemt af mine erfaringer og oplevelser som portør i det her rum, som hospitalet er. Min forståelse af, hvorledes man faktisk kan indtage det rum, den kontekst, man er i, igennem en teknologi, og at den er bestemmende for, hvorledes man overhovedet indtager rummet, det lærte jeg gennem min færdsel i den romerske trafik i denne her frysebil. Det lover jeg jer for var noget af en udfordring. Men det gav mig virkelig en forståelse af, hvorledes vi kropsligt er forbundet med teknologi, og hvorledes vi lærer at leve stedet og rummet igennem teknologien. Så jeg kan parallelparkere med en frysebil.

My: Jeg har lidt svoert ved at høre, fordi der er en dobbeltstemme på, men fik fat $i$, at du noevnte noget om Heidegger. Hvad vil det sige i forhold til dit arbejde? Hvad er det, Heidegger vil om det her teknologi?

Lars: Det begreb, jeg primært relaterer til, er hans gestell-begreb.

Inger: Hvordan vil du oversætte det til dansk?

Lars: Ja, jeg oversætter det, ligesom Dan Zahavi gør. Jeg tror, han er den første, der kommer med den oversættelse af det til dansk, som hedder ,stilladsering“.

Inger: Netop.

Lars: Og det ligger der noget helt andet i end „rammesætning“ eller „enframing"-begrebet, som er den vanlige engelske oversættelse deraf. Hvor det engelske enframing-begreb, der ser man teknologien udelukkende som noget, der stiller os og alt, natur, whatever, som en eller anden stående reserve for udnyttelse. 
Det øjeblik, man læser begrebet som noget, der rammesætter os som en stående reserve, så bliver man jo opfattet i sidste ende som værende teknologidystop. $\mathrm{Hmm}$. Det dér omkring determinisme - jeg mener, der er en form for determinisme i teknikken, som er uomgængelig - og det skriver jeg faktisk også en del om - men den uomgængelighed, som ligger i vores omgang med teknikken, leder ikke nødvendigvis til et eller andet dommedagsscenarie, hvori vi forkastes, forstødes og er fortabte. Det er den der vanlige læsning af Heidegger, som jeg jo bliver meget træt af, fordi der ligger også det andet billede, altså, der er janusansigtet i teknikken/teknologien, som Heidegger konstant peger på. Men man ser aldrig i læsninger, og specielt i engelsk litteratur, det her andet ansigt - hvad skal man sige - håbets ansigt.

Inger: Jeg skynder mig bare lige at sige, hvor er jeg glad for at høre det. Som en fuldstændig amatør, ikke-heideggerianer, men amatørfilosof, har jeg flere gange undervist i Heideggers berømte tekst "Spørgsmålet om teknikken“ fra 1953, og jeg har aldrig vidst, om det, jeg sagde til de studerende, passede med alle heideggerianernes - der virkelig kender ham - med deres udlægning. Men jeg kan i hvert fald sige, at det, jeg har sagt, passer meget godt med det, du siger, Lars. Så det er jeg jo vældig glad for. Og det er jo netop, at der er denne her dobbelthed i det. Man kan ikke sige, at Heidegger er enten teknologidystop eller det modsatte, men han fremlægger spørgsmålet om, hvad teknikken gør ved os, på en ret åben måde, ikke?

Lars: Jo, præcis.

Inger: Så tak for det. Jeg er glad.

Lars: Selv tak [griner].

Inger: Ellers skulle jeg til at løbe tilbage gennem alle årene og sige undskyld til alle de studerende. [Alle griner].

Lars: Men altså det diskussionselement inden for filosofien, som er det miljø, jeg færdes i, også internationalt, det er næsten en provokation at lægge dette åbenlyse og åbenbare frem i sådan nogle teknologifilosofiske diskussioner. Og det skyldes selvfølgelig også, at Heidegger som person er problematisk og anses for at være problematisk, ikke?

Inger: Jo, det bliver lidt blandet ind i det, ikke?

Lars: Og det hele bliver blandet ind og blandet op. Og tingene forplumres.

My: Der er lidt forsinkelse på hos mig, så jeg gør lige sådan her [vinker], når 
jeg gerne vil på. Jeg håber ikke, jeg afbryder nogen. Nu er I jo blevet rørende enige om det her, men I kommer alligevel fra to forskellige retninger eller steder, så måske vi naturligt kunne gå lidt over $i$ det. Det er dig, der holder styr på spørgsmålene, Perle, men jeg tonker, om vi ikke kunne ...

Perle: Det var mit noeste move, så det er fint. Idéen var jo også at prøve at få et historisk perspektiv på, så det ikke kun er, hvad I selv har arbejdet med, og de folk, I er inspirerede af, men også hvordan jeres fag har arbejdet med teknologi from the inception, ncermest.

My: Det er en god indgang. Lad os starte med dig, Inger.

Inger: Ja, okay, det kan godt være, at noget af det kommer lidt senere. Jeg har fulgt lidt jeres spørgsmål og tænkt, at jeg ville starte med at sige, hvordan jeg selv er stødt på teknologi i mit eget forskningsarbejde. Og egentlig kom det sådan lidt bag på mig - altså, hvorfor skal jeg snakke om teknologi? Der er da så mange, der kan - hvorfor skal jeg? Men så gik det jo op for mig, at jeg jo faktisk har skrevet en tekst for nogle år siden, der hedder „Ting og person. Bidrag til en socialitetsteknologi“. Så jeg har brugt begrebet teknologi uden at tænke voldsomt meget over det dengang, men ud fra den fagtradition, som ligger meget tydeligt i antropologien, og som nogen måske vil kalde en lidt metaforisk brug af begrebet teknologi. Det er i hvert fald en brug af teknologibegrebet, som ikke passer ind i meget af den gængse - altså, det er ikke sådan en DTU-teknologi, vel. Det er ikke noget med maskiner og industri, men en meget videre forståelse af begrebet, som jeg gerne vil komme tilbage til med nogle andre eksempler. Men i mit eget arbejde - og især den tekst, der handler om det, der har været gennemgående i mit etnografiske, antropologiske arbejde, nemlig denne her brasilianske religion [candomblé, red.] og dens ritualer, som på en måde er et meget klassisk antropologisk emne, fordi der indgår ritualer, magi, ofret, og der indgår en hel masse socialitetskonstituering gennem nogle af de veje, som nemt bliver opfattet som eksotiske og mærkelige og måske endda primitive. Men hvor det jo er vores opgave som antropologer, og det har jeg i hvert fald set meget som min opgave, at trække det primitive ud af disse religiøse former og vise, hvordan de er noget, man kan lave paralleller til i vores egen verden. Og hvis jeg skal være lidt mere konkret, så er inspirationen til at tale om en socialitetsteknologi, den er virkelig etnografisk, fordi den kommer fra de mennesker selv. Nu skal jeg passe på, at det ikke bliver en alt for lang historie, men ... Jo, hvis vi begynder med Mauss, som enhver antropolog kender ...

Lars: Jeg kender ham også.

Inger: Det tænkte jeg nok! Han taler om magi som en teknologi. Så derfra er der 
også en tradition for at bruge teknologibegrebet ud over den gængse. Og det har jeg arbejdet videre på, kan man sige. Men den etnografiske inspiration kommer fra de mennesker selv. Måden, jeg bedst kan forklare det på kort, er ved at sige, at der er et meget centralt begreb i disse her afrobrasilianske religioner, nemlig begrebet fazer, fordi man taler portugisisk, og det betyder ,at gøre“. Det er også roden til fetichbegrebet, og der er en hel masse med fetich i alt dette her, ikke. Men at gøre det indgår i at være indviet i denne her religion, så er man feito, så er man ,gjort“. Det indgår i alle ofre, al magi. Og ud fra den nøgleposition, som det begreb har, har jeg så udviklet denne her idé om en socialitetsteknologi, som kan karakteriseres som en, der arbejder hen over - og det er så min anden interesse i det - hen over distinktionen mellem ting og personer, mellem materialitet, dødt stof og levende stof, ting og personer, ikke. Og den differentiering, den er der klart, men den bliver hele tiden elaboreret i alt den der gøren: magisk, religiøs, besættelsesorienteret, og hvad det er, rituelt. Ud fra det har jeg prøvet at bruge teknologibegrebet til at sige, hvad socialitet er for noget. Og hvis jeg bare sådan hurtigt skal trække det ud i noget mere velkendt, så er socialitet i vores egen kultur, det samfund, vi kender, jo også noget, der har at gøre med både ting og personer. Og hvis jeg skal læne mig op ad nogle store ånder her, så vil jeg nævne sådan nogle som Georg Simmel eller Norbert Elias, som snakker om civilisation, om etikette, om selskabelighed i Simmels forstand, sociabilitet, som alt sammen også inddrager en eller anden form for elaborering af materialitet. Så I kan høre, at det bliver - i en klassisk etnografisk, antropologisk forstand, men også i en metaforisk og mere hverdagsagtig forstand - en brug af teknologibegrebet som det, hvormed mennesker i deres fællesskaber og omgang med hinanden elaborerer og manøvrerer med ting og med forståelsen af hinanden som subjekter. Socialitetsteknologi. Det er nok det, der kommer nærmest, og så kan jeg sige noget om min kurateringsvirksomhed.

My: Kan I høre mig? [De andre svarer bekraftende] Jeg kan faktisk ikke høre dig, Inger ... Det kan vere, at vi for pingpongens skyld skulle høre Lars lidt og så vende tilbage til det eksempel, som du ville til at fortcelle om nu. Giver det mening?

Inger: Ja, jeg holder pause.

Lars: Ja, afgjort. Jamen, også lidt af, hvad Inger var inde på. Jeg tror, vi er enige $i$ det felt, hvad er teknologi. Hvorledes ser vi teknologi. Jeg har nogle andre referencerammer, men jeg er ikke sikker på, vi er så uenige i sidste ende. For går man tilbage igen til den filologiske undersøgelse af begreberne til technebegrebet, som dem, jeg er inspireret af og konstant søger tilbage til - og det er ikke bare Heidegger, men også Lewis Mumford, den amerikanske urbanist og altmuligmand, og Jacques Ellul, en filosof fejllæst som teknologidystop, fransk 
filosof ... Han skrev The Technological Society. Og også Bernard Stiegler, som er en nulevende fransk filosof, som siger, at vi skal tilbage til den oprindelige betydning af technebegrebet for at løsrive det potentiale, som ligger i teknikken fra den spændetrøje, som teknikken og videnskaben har sat hverandre i i den moderne tidsalder, det vil sige de seneste 200 år. Habermas kalder det en form for „uhellig alliance“, som disse er indgået i sammen med kapitalen. De har ligesom sat hverandre i en spændetrøje, som vi skal have dem revet fri af, således at teknikken, der handler om - som du var inde på, Inger - det at gøre, det at kunne, det at mestre, det at skabe - som nogen fejlagtigt har sagt, så er sublimeringen af dette noget, der sker i kunsten, den fejltagelse gør Heidegger - men lad nu det ligge. Det er ikke kunsten, der har en eksklusiv tilgang til vores forståelse af det at kunne og mestre. Men det, at vi fokuserer på det, vi gør, det, vi skaber, og det, vi laver, i de praksisser, som vi vikler ud, som manifesterer sig i noget konkret. Og jeg forstår godt det der med teknologi som en form for socialisering, eller teknologi er socialisering, eller hvorledes man nu skal læse det. Og der griber jeg nok mere an på Gilbert Simondon.

Inger: Ja, men tak for det! For det ville være min tilføjelse. Ham kender jeg - nu er vi hjemme.

Lars: Ja - at noget konkretiserer sig [griner begge]. Og det der concrétisation, ikke - der skal være noget konkret at forholde sig til. Der skal også være noget, som vi i sidste ende kan måle på. Men det er andet og mere end det, vi kan måle på, som ligger i teknikken. Og derfor forfalder jeg igen til at anvende det, som Heidegger, Mumford, Ellul og Stiegler peger på, nemlig, at det er teknikken og ikke teknologi, vi taler om. Fordi teknologi er for dem, og det er det også for mig, ligesom kontamineret af dette fællesskab med det moderne, naturvidenskab eller videnskaben som sådan, og dermed udfoldes de potentialer, som teknikken besidder, og som videnskaben også besidder i egen ret, ikke. Fordi det er bundet i det her, denne her uheldige alliance, om man så må sige. Og det gør mig ikke til dystop, skal jeg understrege.

My: Jeg har ekstremt svcert ved at høre, hvad du siger. Men kan man måske opsummere, at det er teknik, ikke teknologi, som er der, hvor man kan begynde at udfolde, hvad der foregår? Altså, man skal ikke reducere teknologien til ... teknologi?

Lars: Der er ikke noget teknisk i teknikken, som jo så er den centrale sætning i Heideggers essay fra 1953. Die Frage nach der Technik. Der er ikke noget teknisk. Det handler ikke om, at teknikken i sit væsen blot effektiviserer eller optimerer eller alt det, den også kan - der er langt mere og andet i spil ... Jeg skal have den her pauseting på min computer til ... en gang imellem bliver min skærm sort ... 


\section{My: Ahhh, apropos.}

Inger: Må jeg forfølge denne her lidt? Jeg håber, det supplerer, hvad Lars siger - og jeg er vældig glad for, at du nævnte Simondon. For der er rigtig mange franskmænd, jeg ikke kender, men ham kender jeg lidt til. Og det var en meget glædelig opdagelse for mig at lære ham at kende. Det er faktisk stadigvæk i forfølgelse af mine afrikanske religioner i Brasilien. Men i det er jeg interesseret i, hvordan subjektet opfattes. Simondon snakker om teknik, ikke teknologi i den gængse forstand, men teknik som noget, der har at gøre med forholdet mellem form og indhold, nu siger jeg en konkretisering, jeg ville sige en ... Bruger han ikke begrebet evenement, altså en begivenhed? At det er noget, som opstår. Og som jeg forstår ham, er han optaget af, hvordan noget får form. Og teknik har noget at gøre med formgivning. Og substans og formgivning hænger sammen. Det er jo også sådan noget Aristoteles-halløj, som man tænker ...

Lars: Ja, det rækker der tilbage, og der kunne jeg så have lyst til at trække Heidegger ind igen - det handler om tilblivelses- og tilskikkelsesprocesser, der ligger i det tekniske, og det er jo også det, Simondon peger på. Tilblivelses-, og at noget tager form, tilskikkelsesprocesser. Som ikke er noget eksklusivt menneskeligt, men netop er noget teknisk og noget teknisk, der er i naturen, i mennesket, i tingene, såvel. Det er ligesom distribueret disse imellem.

Inger: Og der kan jeg jo ikke lade være med at tænke på, hvis man skal bringe det ind i en mindre filosofisk og lidt mere konkret, antropologisk sammenhæng, så ligger sådan nogle tanker i den aktuelle brug af eller forståelse af teknologi hos blandt andre, men ikke mindst Tim Ingold, som vistnok også selv har læst lidt Simondon.

Lars: Jeg tror også, at Tim Ingold har læst en hel del fænomenologi.

Inger: Ja, dét har han. Men noget af det, jeg også har lært meget af, det er den måde, Ingold beskriver tilvirkningen af noget som en teknik, ikke. Og der er jeg nok lidt mere ligeglad med naturen i denne sammenhæng. Jeg er interesseret i, hvad mennesker gør med nogle materialer, som også kan være naturlige materialer. Tim Ingold har en rigtig dejlig tekst om at væve en kurv.

Lars: Mmh - kender den godt.

Inger: Som vist også er lidt en nyklassiker. Og hvor jeg synes, han så fint beskriver, hvordan teknikken netop er et forhold mellem en menneskelig agens og en materiel agens, altså et svar. Kurven er ikke et menneske, som kommer og handler på noget. Det er en tilbliven i en proces, hvori indgår også ikke-menneskelige 
størrelser. Altså materialet er med til at bestemme, hvordan den kurv kommer til at se ud, for at sige det banalt, ikke. Og den grundtanke synes jeg er SÅ lækker.

Lars: Ja, og den er jo helt aristotelisk i sin essens, vil jeg næsten sige.

Inger: Helt rigtigt.

Lars: Altså de forskellige kausaliteter, der ligger der, som materialerne har, funktionerne har, og den, der ligesom indskriver tingene, altså designeren, skaberen har.

Perle: Men vil det sige, at vi skal skelne imellem ... Eller vil I så skelne imellem teknik og teknologi?

Inger: Ja, det er da et meget godt spørgsmål.

Lars: Altså, min skelnen ligger i - det kan være, jeg gentager mig selv her - teknologi, måden hvorpå vi forstår den i dag, ser jeg som bundet op på den forbundenhed, der er mellem videnskab og teknik i et stræb imod at effektivisere og optimere på tingene. Mens teknik og teknikken eller teknikker, der er en pegen på praksisser, processer, det at kunne, det at gøre, at skabe, at vi konstituerer os sammen med ting i en verden, som også i sin måde at være på er teknisk. Så ,teknisk“" er noget meget mere og betyder også noget meget større, end hvad teknologi er. Det ville være min umiddelbare distinktion på dem.

Inger: Altså, den kan jeg sagtens være med på. Jeg havde ikke tænkt så meget over det på den led, før vi nu kom til at snakke sammen, og I stiller spørgsmålene, men hvis jeg må blande et af de andre spørgsmål ind i det, nemlig, hvordan vores fag - antropologien - har brugt teknologi, så er der jo, som jeg tidligere har sagt, en meget metaforisk brug af det. Altså, hvis man vil kalde det metaforisk - det kan man diskutere. Men vi har jo Foucaults selvteknologier, ikke. Vi har magi som en teknologi, som jeg har nævnt. Der er en, der hedder Jean-Pierre Warnier, som jeg ikke tror er særlig meget foucaultianer, men han har snakket om magtteknologier, også ud fra studier af afrikanske samfund, han er afrikanist. Jeg kan huske, at vi havde en ph.d.-afhandling for nogle år siden, der hed „Tillidens teknologi“", skrevet af Katrine Nørgaard, som var sådan noget Luhmann-noget. Teknologi indgår på mange måder som et begreb, vi sådan lidt ukritisk bruger til at sige, ,jamen, det er noget med, hvordan man gør noget med noget". Og hvor I nu har opfordret os til det, så tænkte jeg, at jeg skulle definere teknologi. Eller jeg vil sige, for at noget skal kunne kaldes teknologi - nu er jeg ikke helt dér, hvor du var, Lars - så vil jeg sige, at der skal indgå et forhold mellem ting og mennesker, og der skal være noget materielt, der bearbejdes. Og der skal ligge en viden, nogle værdier og nogle forestillinger bag, for at det giver mening at tale 
om teknologi. Men om det så måske hellere skulle være teknik, techne, og man skulle reservere teknologi til det dér ude på DTU, som jeg siger, ikke - det ved jeg ikke, men det er lidt for sent, for vi bruger det i alle mulige sammenhænge inden for fagtraditioner, ikke.

Lars: Ja, ja - præcis. Det er blevet til dette her boundary object, som der er mange forskellige meninger og, hvad kan man sige, holdninger til. Jeg kan huske, at jeg var med til at starte en uddannelse op på Aalborg Universitet før teknoantropologi, der hed Art and technology, og vi spurgte disse unge, håbefulde studerende, der søgte ind på uddannelsen, hvad de lagde i teknologibegrebet. Og de fortalte os, at teknologi, det er noget, man sætter strøm til. Det var sådan meget „bum“ - og det var dét. Man kan sige, at det er et meget snævert teknologisyn. Men det var ligesom det, det var, for 10 år siden. Jeg ved ikke - jeg har ikke stillet spørgsmålet efterfølgende til den følgende generation af unge, men det kan være, at det stadig er det samme.

Inger: Men hvis du slår op i en ordbog, Den store danske - det gjorde jeg da også i dagens anledning - og det bekræftede, hvad jeg måske også kunne have fundet på at sige, hvis jeg var blevet spurgt i en hverdagssammenhæng: at det har noget at gøre med industri. Der står: ,teknologi er omsætning af videnskabelig viden til praktiske formål i industrien“".

Lars: Og der kan du se, at der kommer forholdet mellem oversættelsen af videnskabelig viden til noget $i$ en industriel kontekst.

Inger: Så det er noget med at sætte strøm til. Men jeg ville så bare gerne lave min egen definition, som jeg vil prøve at gøre. Ud fra den måde, jeg har tænkt og brugt det på med socialitetsteknologier og faktisk også det her med kuratering, som jeg også godt kan se som en teknologi, at sætte ting sammen, vælge ting ud, etnografika - men det vil være det samme med en kunstkuratering, vil jeg mene - at vælge ting ud og sætte dem sammen på en måde, så de kommunikerer noget, man gerne vil kommunikere, ikke.

Lars: Ja, ja.

Inger: Der skal være noget materielt, og der skal være nogle mennesker, der gør noget, og så skal der være noget viden, nogle idéer, nogle forestillinger bag. De ingredienser skal være til stede, for at man kan tale om noget som en teknologi, vil jeg mene.

Perle: Jeg har siddet og arbejdet med at skulle lave en forside til dette her tidsskrift, og hvis man slår teknologi op på nettet, så er det noget, man kan satte 
strøm til, og det er digitalt, der er blå billeder af kredsløb og ansigtsgenkendelse og den slags. Jeg bemorkede også, at de antropologer, der arbejder med det $i$ dag, arbejder rigtig meget med digitale teknologier. Og vi havde lyst til at komme bag om det. Så jeg sad først og arbejdede med nogle forsider, der viste nogle industrimaskiner, og tonkte, ej, det gør det ikke. Og så fandt jeg en ske og toenkte, at det er jo en form for teknologi, fordi den indebcerer et materiale og en bearbejdning og en intention, og den lever sådan set op til alt det, du lige har sagt, Inger. Og så er den global. Og så går den tilbage til det tidligste agerbrug, går jeg ud fra, altså noget grød, der flyder så meget, at det skal skovles op. Men den kunne vi heller ikke rigtig forlige os med i redaktionen. Det endte med, at jeg fandt nogle måder at skrive ordet teknologi på, som var en transformering af bogstaverne til noget andet. En metaform. Men på en måde kom jeg hele vejen rundt om meget af det, I har snakket om, ved at sidde og arbejde med denne forside. Som man jo tit gør, når man sidder og skal arbejde med de her forsider - det ved du jo, Inger.

Inger: Ja. Men altså på den måde er det jo et kæmpe, kæmpestort begreb, ikke. For jeg tænkte da også - altså, jeg kan godt lide tanken om skeen og sådan at ... Og hvis man går tilbage i den antropologiske fagtradition, så kan man også - det spurgte I også om ikke, altså, hvordan har man brugt teknologibegrebet dér - så kan man sige, tilbage til dengang, hvor man betragtede det som determinerende $\mathrm{i}$ et evolutionistisk perspektiv. Men jeg forestillede mig jo, at vi uundgåeligt måtte ende i vor tid og måske endda aktuel [corona]tid, ikke. Og på vejen komme forbi de biometriske målinger, som du ved alt om, Perle. Og hele den ... både den digitale teknologi, som man jo også på antropologisk vis arbejder med i science and technology-studier, man er meget inspireret af Bruno Latour og andre, som bruger sådan nogle etnografier blandt folk, der sætter strøm til et eller andet. Men helt op til i dag med - dels overvågningsteknologier, som jo giver eller kan give begrebet socialitetsteknologi en helt ny og meget stærkere og politisk betydning. Og så den digitale udvikling, hvor ... Det er mange år siden, Donna Haraway fortalte os om cyborgs, og nu er der robotter, og så er der digitalisering, og der er vores løbende interaktion as we speak med nogle maskiner, ikke. Altså, hele den rolle, som forskellige af den slags teknologier er kommet til at spille for vores hverdag, og den betydning, det får for politik og demokrati og magt og identitet og alt muligt ... Det bliver jo et kæmpestort begreb. Så spørgsmålet er, om skeen måske ryger lidt i baggrunden. Men jeg vil alligevel sige, at jeg synes, der er en forbindelse. Der er en forbindelse.

My: Jeg tonker også på, nu hvor du siger det, at hvad er forskellen mellem muslingeskaller og denne her computer, du sidder ved nu? I forhold til teknologi, og 
at man gør ud i noget socialt, så det ikke kun er et produkt og et menneske og et ikke-menneske. Det er noget, der medierer, ikke-det er noget af det, vi er ved at komme ind på nu-det er noget, der medierer og former, og som vi former med det sociale og verden $i$ øvrigt. På den måde tcenker jeg, hvad er så forskellen på muslingeskallerne i kularingen, klassisk antropologi, og så det, vi laver nu?

Inger: Jeg henter lige noget ...

My: „Hvem kan få Zoom op at køre?" - Det er de nye muslingeskaller.

Perle: Muslingeskallen, det er jo i allerhøjeste grad en grcensescetning, ikke, mellem muslingekroppen og ...

Lars: Og det omkringliggende.

Perle: Der er en klar intention.

Inger: Man kan måske også spørge - er det en kvantitativ eller en kvalitativ forskel? Mellem muslingeskallen og computeren, vi sidder her med, ikke. Computeren kan en hel del mere og noget meget mere kompleks end muslingeskallen. Men i grundprincippet er det det samme.

Lars: Ja, altså grundprincippet, det holder jeg fuldstændig med dig i, Inger. Grundlæggende så er der ikke sket noget siden dengang i måden, hvorpå vi er sammen med teknikken, hvad teknikken medierer, måden, hvorpå vi forandrer på vores omgivelser. Tingene er blot blevet intensiveret, og så er de eksponentielt steget $\mathrm{i}$ kompleksitet. Men vi har altid forandret på en verden gennem vores interaktioner med teknik og teknologi. Så deri ligger der faktisk også en form for næsten hybris i det der antropocæne begreb, som er så populært lige for tiden - at arbejde med, at vi som mennesker er ved at forandre på verden i sådan en gigantisk kontekst, ikke. Fordi vi har altid været forandrende på den verden, i den kontekst, også ret radikalt, ikke. Vi har skiftet samfundsform og civilisationsform fra én måde til en anden måde, som har haft radikal indflydelse på de omgivelser, som vi er en del af, og den natur, der omgiver os. Så vi har altid været - vil jeg sige - teknoantropocæne. Vi kan i hvert fald ikke sige, at det er antropocænt. Det er teknoantropocænt, hvis det er noget.

Inger: Men det, vi så måske mangler at vide noget om og at indse dybere, er, hvordan vi som menneskelige subjekter og kollektiv fra dag ét med muslingeskallen er blevet formet af de teknikker, teknologier, vi har omgivet os med. Fordi i det antropocæne ligger også, for mig at se, en ... eller jeg ved ikke, det er måske ikke det antropocæne, men antropocentriske. Forestillingen om, at vi står her som menneskelige subjekter, individer, og der sker forskellige ting omkring 
os, og ja, det påvirker os måske nok lidt, men vi er, hvad vi er, i vores krop og i vores sind, og det er der ikke nogen, der har lavet om på, siden Vorherre lavede os, eller hvad man nu tror på. Altså, den tror jeg måske, at man skal revidere en lille smule. For hvis man tænker Ingold eller bare teknisk-teknologisk på det, så er det menneskelige subjekt blevet formet af muslingeskallen, siden hun tog den op og begyndte at gøre noget med den.

Lars: Det er også noget, der ligger i eksempelvis Latours aktør-netværk-teori og også inden for det postfænomenologiske, ikke, som du nævnte, Perle. Altså, at vi er medierede af teknologi $\mathrm{i}$ en verden, hvori vi konstant bliver til og konstituerer os i en flerfoldighed og en flertydighed, som er i konstant, dynamisk udvikling.

Perle: Men i det antropoccene ligger vel, hvis nu vi tager denne muslingeskal, og vi har taget den op og har formet den og puttet den $i$ vores boelter - [holder et muslingebcelte op] du kan købe mange computere for det boelte! - så betyder det antropoccene - eller der antropo-for-sene - vel sagtens, at vi i dag ikke alene former muslingeskallen, når vi har taget den op, men at vi også påvirker den måde, den udvikler sig på og former sig på, når den sidder uden om muslingen.

Inger: Ja. Og når vi nu er der, så vil jeg ikke undlade at vise jer min muslingesamling. Det er mit orakel. Jeg lytter til disse muslingeskaller, og så fortæller guderne mig noget

Perle: Det er meget interessant! Jeg tager bare disse muslingeskaller om maven, og så kan I se, hvor rig jeg er. Købt for alle de grise, mine koner har opdrcettet til mig.

Inger: Sådan nogle har jeg også!

Lars: Det har jeg desværre ikke - hus forbi her.

Perle: Ah, men du har en Putin.

Lars: Ja, det ...

Perle: Men det er jo godt alt sammen - hvad hedder det, når man er gode venner? Men der må veere en grund til, at der bliver undervist $i$ antropologi og teknologi på to forskellige universiteter i København, på KU og så ,ude på Aalborg", som vi siger. Altså, det her teknoantropologi, er det noget nyt, hvis vi skal fortsœtte diskussionen og bringe den mere over $i$ en organisatorisk eller institutionel bane? Hvad er så forskellen på det, der foregår ,, ude på Aalborg “ og inde på Kommunehospitalet? 
Lars: Altså, jeg kan jo svare på, hvad der sker her - jeg kan ikke svare på, hvad forskellen er.

Perle: Men der er altså en forskel - eller?

Lars: Lad os sige det på den måde - og nu kan det være, jeg modsiger lidt mig selv, men det tror jeg nu ikke, jeg gør - der skal være noget konkret at forholde sig til, jævnfør Simondon - der skal ligesom vaere noget. Og dette noget skal også på en eller anden måde kunne sættes i en eller anden kontekst, hvor tingene kan måles og tælles og vejes, uden at vi bliver DTU-agtige af den årsag. Så vi spørger også ind til, det øjeblik, vi eksempelvis forholder os til studerendes projekter: Hvor er teknologien? Eller hvor er teknikken? Hvor er det tekniske system? Fordi det skal projekterne og vores forskning forholde sig til.

My: Og hvad kunne det voere?

Lars: At der er et eller andet ... at der er noget teknik i spil. Langt hen ad vejen kan man måske sige: Hvor er artefaktet?

Perle: Så vi kommer tilbage til ting.

Lars: Ja, hvor er tingen? Hvor er den konkrete ting? Og det viser nok også, hvor uddannelsen er lejret. Fordi den er lejret i en teknisk, naturvidenskabelig kontekst. Og ikke på det humanistiske eller samfundsvidenskabelige fakultet, som klassisk antropologi er. Så der er noget væsentligt forskelligt, både i det institutionelle - det er på teknisk fakultet, og de bliver cand.scient.er i teknoantropologi, dem, der ryger ud herfra.

My: Kan man sige, på en måde, at startstedet er i en ting?

Lars: Ja, startstedet er altid i en ting. Og det er omdrejningspunktet. Det er det også i de forskellige former for modeller, vi udvikler. At teknikken er ligesom kernen, hvorom alting drejer. Og så ser vi på mennesker, og vi ser på sociale grupper, vi ser på samfund og måske også ovenikøbet en verden derude, men omdrejningspunktet er teknik og teknologi. Så vi har ikke mennesket i centrum. Det er ikke et antropocentrisk projekt, det her. Det er et teknocentrisk.

My: Ja, antroproduktcentrisk.

Lars: Jaa ... Nu bliver du måske lidt grov i det [griner].

Inger: Så kan man jo spørge, med alle de posthumanister, der render rundt inde hos os, og inde hos os er antropologi på Københavns Universitet. Hvad er så forskellen? Men den er der. Men jeg troede, det var, og tror lidt stadigvæk, selv om 
jeg er blevet klogere af at høre, hvad du siger, Lars, at så har Aalborg Universitet jo en tradition for at være applied, mere praktisk orienteret end Københavns Universitet. I hvert fald i det her. Og jeg tænkte: Hvor kommer teknoantropologi fra? Jeg vidste det ikke, men det passer meget godt til Aalborg Universitet som en retning, der - og med al respekt for det - forsøger at omsætte videnskabelig viden til praktiske formål. Mens inde hos os på Københavns Universitet kan man få lov til at rende rundt i 20 år og interessere sig for voodoo, som jeg har gjort. Fordi den religion, jeg har studeret, den ligner voodoo, ikke. Altså, det er der jo ikke nogen, der kan bruge til noget som helst, medmindre ... det ved jeg ikke. Det bliver en længere diskussion. Men det bliver en slags grundforskning, som for mig at se sagtens kan spille ind - det håber jeg jo også, det har jeg prøvet $\mathrm{i}$ min undervisning og ved at deltage i sådan noget som det her - spille ind i mere konkrete, aktuelle spørgsmål. Men forskningen er af en anderledes karakter end den, hvor man sigter mod en mere umiddelbar omsættelighed til noget praktisk. Er det ikke rigtigt nok?

Lars: Jo, det er problemorienteret. Der skal være et problem derude. Der skal være et teknisk eller et teknologisk problem derude, som man som forsker eller projektgruppe kan eller skal/bør tage fat i. Så har jeg jo lidt igennem denne seance stået op imod det der med anvendt videnskab eller teknologien som anvendt videnskab eller videnskab som anvendt teknologi - for man kan også vende bøtten, de her to forhold, størrelser, imellem. Og så vil jeg så også sige i den kontekst, at den stemme, I hører her, det er min stemme. Og den repræsenterer ikke, og det ved jeg som et faktum, ikke hele teknoantropologi. Der er forskellige stemmer i spil, fordi vi er tværfaglige. Vi har nogle stærke ingeniørfagligheder oppe i Aalborg - ikke her „ude“ i Sydhavnen - som er knyttet op på teknoantropologiuddannelsen: Så vi har Institut for Kultur og Læring heroppe, som har nogle andre tilgange til det end den, som jeg repræsenterer, og som er mere STS-agtig. Altså den, som Institut for Kultur og Læring repræsenterer, hvor min er mere af den teknologi-filosofiske vending, som jeg har peget på. Det tror jeg er ret væsentligt at få frem, altså, at det er min stemme.

Perle: Ja, det er en duelog.

My: Det er også dig, vi har inviteret, Lars, det er ikke universitetet. Så det er helt fint.

Lars: Ja, det er bare, hvis det lige pludselig står et eller andet sted: „Lars siger, teknoantropologi ... "og så ... Så bliver jeg overfaldet en mørk nat et eller andet sted. 
Perle: Ja, for det er jo det-der er nogle spandinger. Og det er jo dem, man godt kunne have lyst til at finde frem til. Der har svagt forlydt, at det med teknoantropologi faktisk hører til på Aalborg og ikke inde på KU. Så der er et eller andet.

Lars: Altså, det vil jeg jo erklære mig lodret uenig i, og der håber jeg, at I forstår mig ret i forhold til det, vi har talt om i dag. Altså, jeg mener jo, at det at være menneske, det er et teknisk anliggende. Så hvis man taler om antropologi, så er det uomgængeligt, at man ligesom forholder sig til teknik og teknologi.

My: Inger, du ligner en, der gerne vil sige noget ...

Inger: Jamen, jeg er fuldstændig enig, og jeg synes, det er en rigtig god formulering: „Det at være menneske er et teknisk anliggende.“ Og det at være teknik - vil jeg sige, det har jeg ikke lige tænkt grundigt igennem - men hvis man skulle vende den om: Teknik er medbestemmende for, hvad det vil sige at være menneske, uden at være determinerende i nogen absolut forstand. Det er den der interaktion, som jo også ligger i meget nyere teori, som er spændende at blive klogere på. Men jeg har lyst til at tilføje, at det her med teknoantropologi og Aalborg eller København osv. - jeg bliver meget, meget træt, når jeg hører om sådan nogle grænsevogtninger, og nogle gange er de ledsaget af, at noget er finere end andet. At det for eksempel er finere med grundforskning end med applied, anvendt forskning - eller omvendt. Jeg synes, det er fuldstændig noget pjat og lige meget. Vi gør hvert vores. Og der er lidt praktiske, økonomiske, strategiske overvejelser, at nogle må lave noget, der hedder teknoantropologi. Så lad dem dog gøre det. Og så finder vi da ud af det. Og samarbejde eller ... Det er et universelt, menneskeligt anliggende at have med teknik at gøre. Den er jeg helt med på.

My: Som jeg har forstået det, er det mere indgangsvinklen, hvordan man forsøger at undersøge disse ting, hvor der måske er en forskel. Hvor starter man?

Inger: Jo, jo.

My: Det er jo den samme sag på en eller anden måde, man går i gang med at undersøge. Men der er alligevel en forskel.

Inger: Lars sagde meget godt, at det er en problemorienteret tilgang, og der skal være et eller andet teknisk anliggende. Det er der ikke nogen, der siger til os.

My: Det er i hvert fald ikke vores kontekst ... vores empiri, der definerer, om noget er et problem inde ved os. Det er måske mere en problematik $i$ at forstå noget. Det er noget andet, ikke. Det er ikke noget, der skal løses som sådan, men forstås. 
Perle: Men det kan godt vare, vi skal slutte med den. Og med Lars' definition ... Inger: Det var nogle spændende spørgsmål at tænke over. Så tak for det. Lars: Ja, ja ... Jeg har tænkt en del ... 